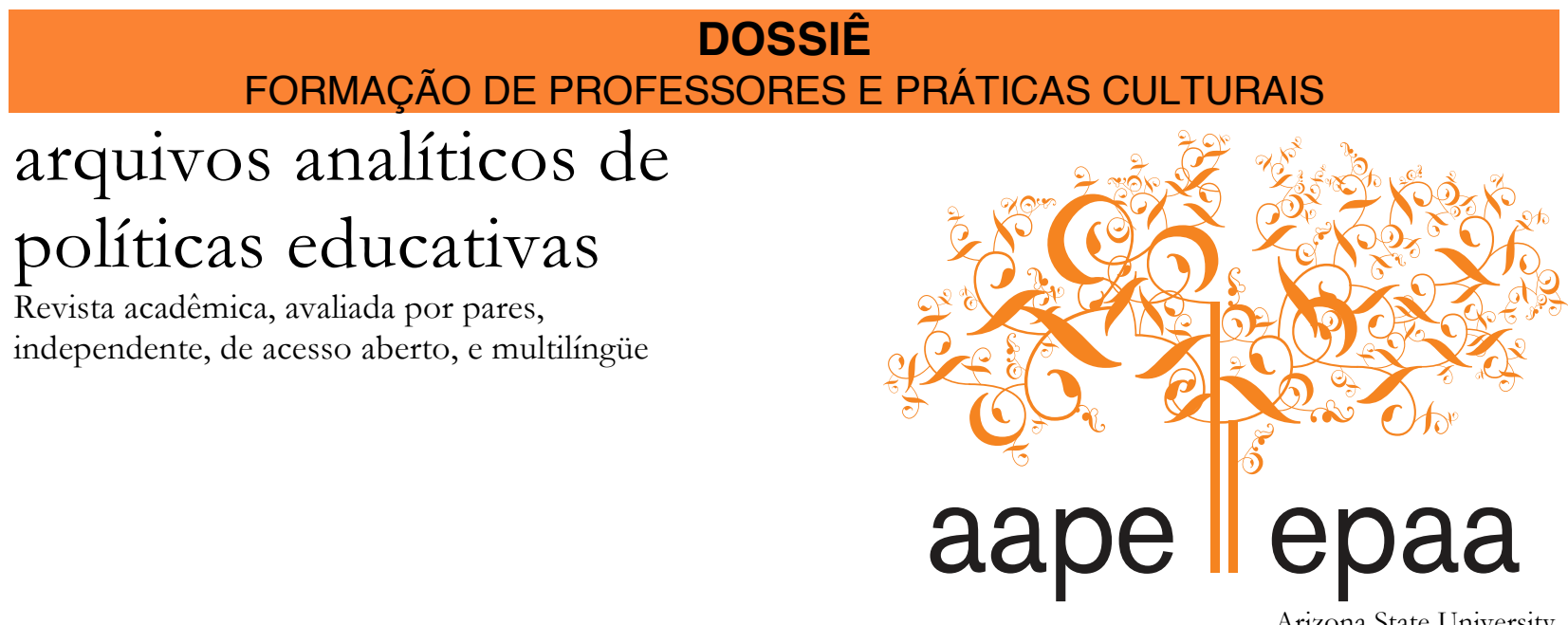

Arizona State University Volume 21 Número $30 \quad 25$ de março, 2013

ISSN 1068-2341

\title{
Educadores De Jovens Trabalhadores Que Estudam: aprendendo a ensinar
}

\author{
Analise Da Silva \\ Universidade Federal de Minas Gerais \\ Brasil
}

Citação: da Silva, A. (2013) Educadores De Jovens Trabalhadores Que Estudam: aprendendo a ensinar. Arquivos Analíticos de Políticas Educativas, 21(30). Dossiê Formação de Professores e Práticas Culturais: descobertas, enlaces, experimentações. Editoras convidadas: Carla Beatriz Meinerz, Dóris Maria Luzzardi Fiss \& Sônia Mara Moreira Ogiba. Recuperado [data] http://epaa.asu.edu/ojs/article/view/1226

Resumo: Os projetos analisados neste artigo foram realizados em 2010 e 2011, com a participação de jovens educandos da EJA (Educação de Jovens e Adultos) cuja faixa etária se situa entre 15 e 29 anos de idade, como atividade de disciplina cursada por seus professores durante a realização do Curso de Pós-Graduação Lato Sensu Especialização em Docência da EJA na Educação Básica: Juventudes Presentes na EJA, por dois semestres letivos. Constatou-se o êxito dos Projetos de Ação no que se refere a vários aspectos avaliados durante seu planejamento e execução, a saber: promoção de aprendizagens para além da sala de aula; percepção da importância de realizar atividades em grupo, formando equipes de estudos e aplicando o apr(e)endido nas oficinas de trabalho, tanto na construção, produção e uso dos recursos tecnológicos como na da economia solidária; promoção da apropriação dos bens culturais, oferecidos por municípios e estado, pelos jovens educandos com a consequente tomada de consciência de que este acesso é direito de todos; e, em especial, fomento ao interesse dos educandos pelas atividades escolares como consequência de se sentirem coresponsáveis por sua aprendizagem. Como resultado verifica-se a ausência de abandonos escolares temporários e uma redução de $37 \%$ no número de faltas esporádicas por parte dos alunos do Curso de Especialização. A reflexão a respeito da ação educativa tratada neste artigo é fruto de um trabalho 
de compilamento de nove projetos desenvolvidos em um curso com enfoque nas juventudes presentes na EJA. Esse esforço é submetido a uma abordagem teórica e metodológica libertadora, segundo princípios buscados, sobretudo, em Paulo Freire, o que lhe confere rigor e qualidade acadêmicos. Observou-se, na prática cotidiana, o diálogo entre os projetos relatados em interface com uma fundamentação teórica capaz de explicitar avanços teórico-epistêmicos para o campo da Educação de Jovens e Adultos.

Palavras-chave: Educação de Jovens e Adultos; Juventudes Presentes na EJA; Prática Pedagógica; Construção de saberes; Currículo e Docência.

\section{Educators Of Young Workers Who Study: Learning to Teach}

Abstract: The projects analyzed in this article were done in 2010 and 2011, along with the participation of young learners from YAE (Youth and Adults Education) whose age is between 15 and 29 years old, as an activity of the subject coursed by their teachers during the accomplishment of the Post-Graduate Specialization in Teaching Sensu Lato of YAE in Basic Education: Youth Attending the YAE, for two semesters. It was observed the success of the Action Projects with regard to various aspects evaluated during its planning and execution, as follows: promoting learning beyond the classroom; the perception of the importance to perform group activities, building study groups and applying what was learnt in workshops, both in the construction, production and use of technological resources as in the solidary economy; promoting the appropriation of cultural property, offered by counties and state, by young learners with consequent awareness that this access is a right for all; and, in special, fostering to the interest of the learners for the school activities in order to make them feel co-responsible for their learning. As the result it is seen no temporary school dropouts and a $37 \%$ reduction in the number of sporadic absences by students of the Specialization Course. A reflection on the educational activities addressed in this article is the result of a compilation of nine projects developed in a course focusing on youths present in the YAE. This effort is subjected to a liberating theoretical and methodological approach, according to the searched principles, especially at Paulo Freire, which gives it academic rigor and quality. It was observed, in the daily practice the dialogue between the projects reported in interface with a theoretical foundation able to explain the theoretical- epistemic advances to the field of Education for Youths and Adults.

Key words: Youth and Adults Education; Youths Attending the YAE; Pedagogical Practice; Building knowledge; Curriculum and Faculty.

\section{Educadores De Jóvenes Trabajadores Que Estudian: aprendiendo a enseñar}

Resumen: Los proyectos analizados en este artículo se llevaron a cabo en 2010 y 2011, con la participación de jóvenes estudiantes de EJA (Educación de Jóvenes y Adultos) cuya edad está entre 15 y 29 años de edad, como actividad de la asignatura cursada por sus profesores durante la realización del curso de Posgrado en Lato Sensu Especialización en Docencia de EJA en la Educación Básica: Juventudes Presentes en EJA, durante dos semestres. Se constató el éxito de los Proyectos de Acción con respecto a diversos aspectos evaluados durante su planificación y ejecución, a saber: promoción del aprendizaje más allá del aula, la percepción de la importancia de realizar actividades de grupo, formando equipos de estudios y aplicando lo apr(e)endido en los talleres de trabajo, tanto en la construcción, producción y uso de los recursos tecnológicos como en la de la economía solidaria, promoción de la apropiación de los bienes culturales, ofrecidos por los municipios y por el estado, por los jóvenes estudiantes con la consecuente toma de conciencia de que este acceso es un derecho de todos y, en particular, fomento al interés de los alumnos por las actividades escolares como resultado de sentirse co-responsables de su aprendizaje. Como resultado, se percibe la ausencia de abandonos escolares temporarios y una reducción del 37\% en el número de faltas esporádicas por 
los estudiantes del Curso de Especialización. Una reflexión sobre la acción educativa tratada en este artículo es el resultado de un trabajo de compilación de nueve proyectos desarrollados en un curso centrado en las juventudes presentes en EJA. Este esfuerzo se somete a un enfoque teórico y metodológico liberador, de acuerdo con los principios buscados especialmente en Paulo Freire, que da rigor y calidad académicos Se ha observado en la práctica cotidiana, el diálogo entre los proyectos relatados en la interfaz de un marco teórico capaz de explicitar avances teóricos-epistémicos para el campo de la Educación de Jóvenes y Adultos.

Palabras clave: Educación de Jóvenes y Adultos; Juventudes Presentes en EJA; Práctica Pedagógica; Construcción de saberes; Currículum y Docencia.

\section{Introdução}

O sujeito jovem, ao chegar à Educação de Jovens e Adultos (EJA), traz consigo uma leitura de mundo que implicará no desenvolvimento de uma melhor aprendizagem nas práticas relacionadas ao meio em que vive. Reconhecer esse fato é essencial para o esenvolvimento de uma sociedade que incorpore esse jovem de maneira justa e igualitária. Como entendido por Freire (2002), na EJA, é importante que o indivíduo seja visto e percebido como sujeito de sua aprendizagem, que a sua cultura seja valorizada e que exista também a apresentação de novas possibilidades. Partindo da realidade e dos interesses do educando, é desejável que a EJA vise à conscientização e autonomia desses sujeitos frente aos desafios postos pela nossa estrutura econômico-social.

Este artigo reflete sobre as práticas pedagógicas dos educadores cursistas de um Curso de PósGraduação Lato Sensu Especialização em Docência da EJA na Educação Básica: Juventudes Presentes na EJ $A^{1}$ que teve como ênfase a especificidade da presença de jovens educandos nessa modalidade de ensino, levando em consideração esta juvenilização nas escolas dos nove municípios participantes ${ }^{2}$. Portanto, ao mencionar, neste artigo, os trabalhos de campo e demais atividades, propomos uma ressignificação da sala de aula, a fim de reconstruir as formas de ensinar e de aprender que estão consolidadas no ambiente escolar.

O conceito de educadores adotado por nós, neste artigo, considera a centralidade da postura dodiscente que necessita de uma abertura dos sujeitos envolvidos que oportunize a apreensão dos outros conhecimentos. O educador é, assim, um pesquisador, uma vez que tem curiosidade. Dessa forma, o educador não transfere os conhecimentos, e, sim, cria possibilidades para a sua própria construção e apropriação, devendo estar preparado e aberto a indagações suas e dos educandos com os quais trabalha.

Já o conceito de juvenilização aqui tratado pauta-se no jovem como aquele sujeito do qual socialmente se espera a construção do "novo" compreendido no sentido que Hannah Arendt (1972) dá ao termo no texto "A crise da educação", ou seja, não se trata do novo como a novidade, mas, desde a dimensão da criação que entendemos como adequada à nova geração. Entretanto, enfocamos igualmente os fenômenos sociais que vivemos e que evidenciam que poucos professores se percebem em condições de tratar os jovens a partir do lugar da diferença e da alteridade na relação. Isso seria produto daquilo que o historiador Eric Hobsbawm denomina de juvenilização da cultura, ou seja, como adverte Maria Rita Kehl (2004), dos 18 aos 50 todos são jovens, ninguém mais quer ocupar o lugar do adulto, fenômeno ao qual a psicanalista chama teenagização. Avaliamos que

\footnotetext{
${ }^{1}$ Esse Curso foi uma resposta à demanda apresentada ao MEC pelos Fóruns de EJA do Brasil (http://www.forumeja.org.br/) e atendeu ao Edital da Resolução 48 do FNDE, que estabeleceu orientações para a apresentação, seleção e apoio financeiro a projetos que visassem à oferta de cursos de Formação Continuada na Modalidade de Educação de Jovens e Adultos no formato de Cursos de Extensão, Aperfeiçoamento e Especialização. ${ }^{2}$ Coronel Fabriciano, Divinópolis, Ipatinga, Nova Lima, Raposos, Ribeirão das Neves, Sabará, Timóteo e Santa Luzia
} 
os jovens se sentem como que desamparados, pois esperam dos adultos o mesmo que esses esperam dos jovens. Assim, o jovem passa a ser o modelo em diversos sentidos, e o adulto que ocupava o lugar de paradigma acaba por se espelhar nele.

Esse Curso aconteceu de setembro de 2010 a dezembro de 2011 e teve carga horária de 405 horas. Os objetivos principais foram: aprofundar estudos e análises sobre a prática desenvolvida nos espaços educativos, formando teórica e metodologicamente, em nível de especialização, 80 (oitenta) educadores e educadoras das Redes Municipais e Estadual de Educação, que atuam no Ensino Fundamental e Médio no estado de Minas Gerais. Para isso, temáticas específicas foram selecionadas como referência para a organização curricular do referido Curso conforme necessidades evidenciadas por avaliação de educadores e educadoras e das próprias instituições gestoras, definidas como núcleo obrigatório, presentes em pesquisas que tratam do tema. Assim, todos os cursistas pósgraduandos cursaram todas as disciplinas e oficinas bem como produziram todas as pesquisas previstas na organização curricular.

O Curso pretendeu favorecer o desenvolvimento de estudos e atividades que possibilitassem uma estreita articulação entre o debate teórico-epistemológico e a prática dos educadores e educadoras no cotidiano da escola, da sala de aula e dos demais espaços educativos onde atuam. Pretendeu, ainda, constituir espaços de integração entre os educadores e educadoras agrupados/as, inicialmente, pela mistura dos níveis de ensino de atuação, das áreas de formação inicial e das redes de origem, na perspectiva de consolidar trocas de experiências e diálogos sobre os desafios da realidade dos espaços educativos e da educação brasileira, ampliar conhecimentos e promover a realização de processos de reflexão abrangentes a respeito das práticas docentes, dos reconhecimentos identitários e políticas públicas de educação em EJA.

As temáticas/especificidades contempladas durante a execução deste Curso foram as da Educação de Jovens e Adultos voltadas à população urbana, à juventude, às variadas diferenças com foco no grande desafio de contribuir para a redução das possibilidades de aplicação da falsa sinonímia entre desigualdade e diferença. O Curso buscou colaborar com a Formação Continuada de educadores e educadoras e com a ampliação da possibilidade de tornar efetiva a principal diretriz da UNESCO: proporcionar educação de qualidade social para todos e ao longo da vida. A constituição do Curso foi baseada no acúmulo conceitual e metodológico já desenvolvido e em construção pelos Núcleos de Estudos e Pesquisas da Faculdade de Educação (FaE) da Universidade Federal de Minas Gerais (UFMG), em especial, pelo Núcleo de Educação de Jovens e Adultos (NEJA).

Todas as disciplinas foram obrigatórias: Conhecendo os Sujeitos da EJA e Suas Diferentes Diferenças; Conhecimento Geográfico na EJA; Construção do Conhecimento Científico na EJA; Educação de Jovens e Adultos; EJA e o Mundo do Trabalho; Expressão Corporal e Artística; Legislação e Políticas Públicas de Educação de Jovens e Adultos; Letramentos na EJA; Metodologia de Pesquisa em EJA; Numeramento; Oficinas de Trabalho na EJA; Paulo Freire e Educação Para a Justiça Social; Processos de Construção Coletiva na EJA; Recursos Tecnológicos Digitais na EJA; Saberes Históricos na EJA; Trabalhos de Campo na EJA e Juventudes Presentes na EJA.

Foram 42 os municípios que atenderam ao nosso chamado para participar. Entretanto, devido ao atraso de dezoito meses para o início da Especialização e à mudança de administrações municipais em virtude de eleições, em setembro do ano de 2010, somente 11 dos 853 municípios mineiros participaram do Curso. Ao final de 2011 e até o momento da escrita deste artigo, em 2012, recebemos correspondências físicas e digitais de gestores que nos informam os impactos trazidos pela parceria à qualidade da EJA nos municípios participantes. E, em função desse retorno, recebemos também solicitação de muitos outros municípios de reedição do mesmo, evidenciando a intenção de firmar futuras parcerias. 
Avaliando que se faz necessário destacar o sentido que a Educação de Jovens e Adultos tem para os sujeitos das vivências aqui registradas, tomamos emprestadas palavras de Paulo Freire e fazemos de seu pensamento nossas palavras, por entender que o processo ensino-aprendizagem não pode se fazer de cima para baixo, nem de fora para dentro, como uma doação ou uma exposição, mas de dentro para fora pelo próprio sujeito, mediado pelo educador. A conscientização "não pode existir fora da 'práxis', ou melhor, sem o ato ação-reflexão" (Freire, 1980, p. 26).

Essa é a razão pela qual procuramos uma metodologia que fosse capaz de se constituir instrumento do educando, e não apenas do educador, e que identificasse, como claramente observou um jovem sociólogo brasileiro, o conteúdo da aprendizagem como processo de aprendizagem. Neste modo de pensar a prática, observa-se a busca por ampliar não somente os conhecimentos, mas apontar caminhos aos desafios surgidos, provenientes das relações entre os sujeitos.

Durante o Curso, todos os cursistas se envolveram com a elaboração de Projetos de Ação, que foram desenvolvidos em suas atividades docentes, demonstrando, em sua proposição, a apropriação dos elementos reflexivos presentes no trabalho com cada uma das temáticas/especificidades e com o apontamento de diálogos possíveis entre elas. Tal atividade foi desenvolvida por meio da produção de um trabalho realizado individualmente, em tempos não previstos na integralização curricular, propondo uma ação a ser realizada junto a cada turma e envolvendo a juventude presente nas salas de aulas. O formato de apresentação foi o de um dossiê de atividades práticas desenvolvidas no espaço educativo com reflexão crítica. Através da execução dos Projetos de Ação, pretendemos obter dados referentes às dificuldades encontradas por educadores e educandos em sala de aula, bem como sobre a realidade vivenciada por esses, sugerindo alternativas para o desenvolvimento de uma relação ensino-aprendizagem mais adequada para a EJA. Para Freire (1987, p. 17),

[...] objetivar o mundo é historicizá-lo, humanizá-lo. Então, o mundo da consciência não é criação, mas, sim, elaboração humana. Esse mundo não se constitui na contemplação, mas no trabalho. Na objetivação transparece, pois, a responsabilidade histórica do sujeito: ao reproduzi-la criticamente, o homem se reconhece como sujeito que elabora o mundo; nele, no mundo, efetua-se a necessária mediação do auto-reconhecimento que o personaliza e o conscientiza como autor responsável de sua própria história. O mundo conscientiza-se como projeto humano: o homem fazse livre. [...]. Reencontrar-se como sujeito, e liberar-se, é todo o sentido do compromisso histórico. (Freire, 1987, p. 17).

Assim, o processo de conhecimento e aprendizagem dos sujeitos da EJA precisa ser construído entre educandos e educadores, para que a visão de mundo de cada um possa ser provocada, produzida, compreendida e ampliada nas mais diversas situações trazidas de cada espaço da sociedade, de acordo com a realidade social e cultural desses sujeitos. Reconhecer o mundo e reconhecer-se nele é tarefa de educadores e educandos da EJA que buscamos realizar durante a concepção e a implementação dos Projetos de Ação em questão. Adotando uma relação pessoal igualitária perante o educando, favorecendo o diálogo e propiciando uma nova visão de mundo, problematizando a realidade em que se encontra, o educador colaborou no processo de reflexão do educando sobre os conhecimentos adquiridos e o movimento inverso também estabeleceu-se na relação.

\section{Interfaces da EJA}

\section{As juventudes, a EJA, a escola}


Segundo o Documento Base Nacional Preparatório à VI Confintea ${ }^{3}$, a chegada dos jovens urbanos, moradores de periferias, com histórico de escolarização recente, filhos das classes trabalhadoras, na EJA, é o reconhecimento de maciça presença de grupos etários integrantes da categoria histórica jovem. Um questionamento que nos acompanhou, durante a escrita e execução dos Projetos de Ação, foi: o que tem levado os jovens dos nove municípios participantes do Curso de Especialização em questão a se matricularem na EJA? Há várias possibilidades de respostas. Entretanto, nesse momento, o levantamento das mesmas não é nosso objeto de escrita. ${ }^{4} \mathrm{~A}$ centralidade da questão reside em assumir que, atualmente, esses jovens estão sob a égide da EJA, e que nos cabe, enquanto educadores, garantir a eles as mais diversas oportunidades de aprendizagem com qualidade social. Outros questionamentos também surgiram, como: existe convivência harmoniosa entre as gerações presentes na EJA? O que promove essa harmonia? Harmonia tem sido analogia para anulação das diferenças?

Evidenciou-se, a partir dos questionamentos aqui expostos, que a harmonia entre as gerações foi evidenciada em diferentes momentos dos projetos e, em sua maioria, sendo associada pelos cursistas ao acolhimento: o mais velho acolhe o jovem como filho, neto, aconselha, corrige em muitos momentos. Foi possível perceber que parte dessa juventude não tem uma figura adulta como referência positivada e acaba transferindo essa referência para colegas adultos. De igual maneira, percebeu-se o empenho dos jovens em colaborar no aprendizado dos adultos, oferecendo-se, em diversas situações, para ajudar nas explicações individuais aos colegas.

Portanto, o que pesquisamos nos autoriza dizer que a relação respeitosa, cidadã e companheira entre os educandos, e desses com os educadores com os quais partilham saberes e sabores, é um fator preponderante para que os primeiros se sintam mobilizados para a construção do conhecimento. Esse envolvimento é fruto do significado atribuído pelos jovens educandos à sua convivência com os outros educandos, quer adolescentes, quer jovens, quer adultos, quer idosos, e com os educadores. Foi possível observer, na convivência entre esses sujeitos, o que Freire propõe na tendência pedagógica libertadora. Segundo Freire,

Porque é um ato de coragem, nunca de medo, o amor é compromisso com os homens. [...] o ato de amor está em comprometer-se com sua causa. A causa da libertação. Mas este compromisso, porque amoroso, é dialógico. Como ato de valentia, não pode ser piegas: como ato de libertação, não pode ser pretexto para a manipulação, senão gerador de outros atos de liberdade. A não ser assim, não é amor. Somente com a superação da situação opressora é possível restaurar o amor que nela estava proibido. Se não amo o mundo, se não amo a vida, se não amo os homens, não me é possível o diálogo. (Freire, 1987, p. 80).

[...] que saibamos que, sem certas qualidades ou virtudes como amorosidade, respeito aos outros, tolerância, humildade, gosto pela alegria, gosto pela vida, abertura ao novo, disponibilidade à mudança, persistência na luta, recusa aos fatalismos [...] abertura à justiça, não é possível a prática pedagógico-progressista, que não se faz apenas com ciência e técnica. (Freire, 1998, p. 136).

[...] não é possível o diálogo entre os que querem a pronúncia do mundo e os que não a querem; entre os que negam aos demais o direito de dizer a palavra e os que se acham negados desse direito. E preciso, primeiro, que, os que assim se encontram

\footnotetext{
${ }^{3}$ Brasil. (2008) Documento Base Nacional Preparatório à VI CONFINTEA. Brasília. MEC, 2008. Acessado em 12 set. 2011. Disponível em: http://portal.mec.gov.br/arquivos/pdf/documento final.pdf.

${ }^{4}$ Aos interesados em aprofundar a questão, sugerimos a leitura de Mileto ( 2009); Martins (2011); Brunel (2008); Andrade (2004) e Dayrell (2001; 2003).
} 
negados no direito primordial de dizer a palavra, reconquistem esse direito, proibindo que este assalto desumanizante continue. (Freire, 1987, p. 78).

Como educador preciso ir "lendo" cada vez melhor a leitura do mundo que os grupos populares com quem trabalho fazem de seu contexto imediato e do maior de que o seu é parte. O que quero dizer é o seguinte: não posso de maneira alguma, nas minhas relações político-pedagógicas com os grupos populares, desconsiderar seu saber de experiência feito. Sua explicação do mundo de que faz parte a compreensão de sua própria presença no mundo. E isso tudo vem explicitado ou sugerido ou escondido no que chamo "leitura do mundo" que precede sempre a "leitura da palavra". (Freire, 2000, p. 81)

O desafio de ler o mundo com o qual trabalham foi outro questionamento muito frequente. Esse desafio acompanhou educadores e educandos envolvidos nos Projetos de Ação. A conclusão dos educadores, pautada nas falas dos educandos jovens, corrobora o que dizem pesquisas, como a de Sposito (1997, 2002, 2009), Sposito e Carrano (2003), Abramo (2005) e Abrantes (2003): os educandos jovens da EJA buscam a oportunidade de escolarização, são oriundos das camadas populares, em sua maioria são negros e moradores dos bairros periféricos das cidades, a cada semestre estão presentes em maior número na formação das turmas, fazendo com que a EJA esteja passando por um processo denominado juvenilização por alguns pesquisadores, já trazem suas visões de mundo, seus desejos, suas experiências, e são também marcados por processos de exclusão, pois são trabalhadores, alguns empregados, outros não, fazendo parte do mercado de trabalho, seja ele formal ou informal, alguns encaminhados por escolas de Educação Especial.

Faz-se necessário afirmar que, nos últimos anos, o processo de mudanças chamado de "juvenilização" vem se intensificando e provocando alterações significativas na EJA. Ressaltamos que adolescentes, jovens, adultos e idosos sempre estiveram presentes na Educação de Adultos, como é possível observar em Freire (1995):

Os critérios de avaliação da idade, da juventude ou da velhice, não podem ser os do calendário. Ninguém é velho só porque nasceu há muito tempo ou jovem porque nasceu há pouco. Somos velhos ou moços muito mais em função de como pensamos o mundo, da disponibilidade com que nos damos curiosos ao saber, cuja procura jamais nos cansa e cujo achado jamais nos deixa imovelmente satisfeitos... Somos moços ou velhos muito mais em função da vivacidade, da esperança com que estamos sempre prontos a começar tudo de novo, e se o que fizemos continua a encarnar sonho nosso, sonho eticamente válido e politicamente necessário. Somos moços ou velhos se nos inclinarmos ou não a aceitar a mudança como sinal de vida e não a paralisação como sinal de morte...O melhor tempo para o jovem de 22 ou de 70 anos é o tempo que se vive. O ideal é quando se junta à disponibilidade da juventude a sabedoria acumulada do "velho" que se manteve jovem. (Freire, 1995, p 56-57).

Entretanto, atualmente, os motivos que trazem os jovens de volta à escola que abandonaram, ou pela qual foram abandonados, há não muito tempo, são outros. Com isso, surgem novos desafios para educadores da EJA aqui entendidos como: professores, pedagogos e diretores que veem o ambiente escolar se modificando com novas formas de linguagem, aprendizagem, cultura e convívio e, assim, demandando a modificação de suas práticas pedagógicas também.

Essas juventudes estão chegando até a EJA, provavelmente, por alguns motivos que julgamos relevantes mencionar. Um primeiro tem relação com o momento econômico pelo qual o Brasil passa nos últimos anos. Com o constante crescimento da economia e geração de postos de trabalho em larga escala, muitos jovens são atraídos pelas oportunidades de trabalho e aqueles que as alcançam acabam por abandonar a escola, muitas vezes movidos por atender seus anseios pessoais, 
para ajudar no sustento da família ou até mesmo pela incompatibilidade de horários ou o cansaço físico. No entanto, um segundo motivo diz que parte desses jovens regressa à escola com o intuito de concluir os estudos devido à exigência imposta pelo mercado de trabalho. Observe-se que a Região Metropolitana de Belo Horizonte vive, segundo dados do Departamento Intersindical de Estatística e Estudos Socioeconômicos (DIESSE), situação de pleno emprego desde o ano de 2010. Muitas empresas buscam conseguir certificados de qualidade que exigem um nível educacional mínimo de todos os seus funcionários. Dessa forma, eles retornam pela necessidade e pela oportunidade de construírem seus conhecimentos e partilharem saberes na EJA. Peregrino e Carrano (2003) também identificaram esse mesmo desafio:

Mesmo com a melhoria relativa nos índices de escolaridade apontada pelo Censo 2000, a grande maioria dos jovens brasileiros não consegue chegar ao ensino médio nem ao ensino superior. Ainda que a taxa de analfabetismo na população acima de 10 anos de idade tenha caído de 19,7\% em 1991 para 12,8\% em 2000, muitos adolescentes e jovens são obrigados a sair da escola para trabalhar e ajudar no sustento da família (p. 14).

Importante citar um terceiro motivo, uma vez que alguns jovens são expulsos dos turnos escolares diurnos nos quais estão matriculados ou transferidos de outras escolas por questão de inadaptação às normas disciplinares, ou por dificuldades de aprendizagem. Muitas vezes, insatisfeitos com as práticas pedagógicas utilizadas por seus educadores, os jovens não encontram na escola perspectivas para aquilo que foram buscar, não conseguem nenhum avanço, não têm nenhum incentivo, não recuperam sua auto-estima, não dialogam e, assim, não encontram motivos para permanecerem nesse ambiente. Resultado: acabam abandonando os estudos e seguindo outros caminhos. Esses, em sua maioria, possuem uma idade incompatível com o ano escolar em que estão ou que deveriam estar cursando e, por isso, encontram dificuldades para serem aceitos em outras escolas. Dessa forma, resta-lhes, como última opção, a EJA.

Os jovens que encontram na EJA algum elemento, que os permite estabelecer vínculos e relações de pertencimento com o ambiente escolar, provocam uma mudança estrutural e cultural nessa modalidade. Essas mudanças vão além da linguagem, da forma de vestir ou de agir, e são percebidas pelos adultos e pelos idosos que estão no processo. Muitos desses jovens vão à escola com a ideia de não estudar, ou seja, frequentam a EJA com o intuito de repetir o que faziam nas escolas onde estavam inseridos antes. Isso vem provocando reclamações e incômodos nos adultos que acabam vendo nisso um motivo ou um pretexto para abandonar a escola.

Alguns educadores também relatam dificuldades encontradas durante as aulas para lidar com esse conflito de gerações dentro da sala de aula. A diferença etária, por si só, na maioria das vezes, determina objetivos diferentes. Alguns adultos e jovens, que já estão no mercado de trabalho, buscam recuperar a oportunidade que, em algum momento da vida, lhes foi negada por algum motivo, ou completar seus estudos, outros jovens ingressaram na escola por imposição das famílias que os sustentam ou por encaminhamento do conselho tutelar. Eles não compreendem a escolarização como um de seus objetivos de vida.

Mais um fator que vem provocando certo desconforto entre esses jovens, adultos e idosos diz respeito à capacidade de assimilação dos conteúdos. Enquanto os jovens o absorvem mais rapidamente, em função da vivência escolar mais recente, os adultos e idosos demandam, às vezes, tempo e dedicação maiores. Isso cria uma impaciência em ambos os grupos e provoca, às vezes, o abandono da escola tanto por parte dos jovens como dos adultos e idosos. Entretanto, não evadem de modo definitivo, pois, no ano seguinte, lá estão eles novamente superlotando as salas de EJA nos primeiros meses de aula.

Assim, o ambiente escolar da EJA passa por um processo de transformação lento, porque nele estão envolvidas questões etária, didática, espacial (ambiente escolar) e cultural. Pensando 
possibilidades de colaborar com algumas alternativas para o impasse criado pelas situações narradas, educadores-cursistas apresentaram, como resultado da pesquisa realizada, uma proposta de Projetos de Ação Integrados.

Todos os projetos seguiram alguns passos, definidos coletivamente, entre cursistas e orientadora, a fim de garantir clareza na proposta metodológica e coerência entre ela e os objetivos do trabalho. O estabelecimento de um diagnóstico foi o primeiro passo e fez parte de um processo e de uma escuta de educandos e educadores. O segundo passo foi a elaboração da proposta de ação. Analisada coletivamente a proposta e devidamente estruturada, passamos à sua apresentação aos demais educadores das redes de ensino municipais envolvidas e ao posterior convite a que se integrassem a ela. O quarto passo implicou apresentar a proposta aos educandos, em sua versão ainda não final, e reestruturá-la a partir do olhar desses sujeitos. O quinto passo envolveu os primeiros trabalhos de campo.

Entendemos o trabalho que desenvolvemos como sendo caracterizado pela "construção coletiva de um saber, de análise da realidade, de confrontação e intercâmbio de experiências" (Candau, 1999, p. 23), em que o saber não se constitui apenas no resultado final do processo de aprendizagem, mas também, e principalmente, no próprio processo de construção do conhecimento. Dessa forma, desenvolvemos uma experiência de ensino e aprendizagem em que educadores e educandos construíram juntos o conhecimento num "tempo-espaço para vivência, a reflexão, a conceitualização: como síntese do pensar, sentir e atuar. Como 'o' lugar para a participação, o aprendizado e a sistematização dos conhecimentos" (Gonzáles Cubelles, 1987, p.18).

Assim, contamos com a contribuição de Veiga (2011) e de Freire (1998), para quem a docência é formulada como uma ousadia, ou seja, uma prática inconformada com o estado de coisas social, simultaneamente alimentada pelo profissionalismo e pelas virtudes inerentes a essa profissão: "Ao estudo crítico corresponde um ensino igualmente crítico que demanda necessariamente uma forma crítica de compreender e de realizar a leitura da palavra e a leitura do mundo, leitura do texto e leitura do contexto" (Freire, 1998, p. 33). A docência é, portanto, exercício da tarefa educativa, orientada para a transformação, sempre numa perspectiva dialógica e pesquisadora: o senso crítico.

\section{Outras práticas pedagógicas na EJA são possíveis, urgentes e necessárias}

Para tratar dessas outras práticas, descreveremos os projetos desenvolvidos. Freire (2002) ajuda-nos a explicitar nossa intenção quando diz que é fundamental:

que saibamos que, sem certas qualidades ou virtudes como amorosidade, respeito aos outros, tolerância, humildade, gosto pela alegria, gosto pela vida, abertura ao novo, disponibilidade à mudança, persistência na luta, recusa aos fatalismos [...], abertura à justiça, não é possível a prática pedagógico-progressista, que não se faz apenas com ciência e técnica. (Freire, 2002, p. 136).

Competir com a grande mídia e seus interesses atrelados ao sistema capitalista, por vezes, parece-nos praticamente impossível! Para buscar alternativas a essa situação é necessário se estabelecer uma sintonia entre a escola e a realidade. Se isso não for concretizado, os temas serão tratados como mera informação discutida em tempos de 50 minutos entrecortados, às vezes, por um toque de celular.

\section{Praticando a Matemática nas Tecnologias}

É extremamente necessário adequar as questões abordadas na escola à realidade vivenciada pelo educando, por exemplo, aliando as Novas Tecnologias de Informação e Comunicação ao que a escola disponibiliza. Maneiras de fazer isto podem envolver ações como: propor pesquisas sobre determinados temas em livros e na internet; comparar o impacto, demonstrando que a atualização de 
dados e fatos processados pela Internet, em sites confiáveis, supera algumas publicações, com exceção de livros que são referências; ressaltar, ainda, que o acesso às bibliotecas da escola ou do município, às vezes, não é tão fácil como a um computador. Embora pareça absurdo aos que não estão familiarizados com o cotidiano da escola que oferta EJA, é frequente que não se disponibilize aos educandos dessa modalidade o acesso à biblioteca escolar, o que configura uma lesão as seus direitos. Além disso, algumas escolas não têm biblioteca e outras tantas têm um espaço chamado biblioteca que, na verdade, guarda apenas livros didáticos nem sempre atuais e adequados aos educandos jovens e adultos.

Outra proposta importante é trabalhar com os educandos a compreensão de que os "ctrl c"5 e "ctrl v" produzem um conhecimento autoral. Esta poderia ser uma temática para um bom debate sobre o que se espera do educando ao indicar uma pesquisa. A sugestão de sua inclusão, entre as práticas construídas com os educandos, resulta das observações feitas em sala de aula a partir das quais se constatou que um debate é capaz de expandir um tema muito mais do que um trabalho escrito limitado em páginas, ainda que um trabalho não exclua necessariamente o outro. Os educandos, especialmente da EJA, recebem bem essa metodologia amplamente defendida por Paulo Freire. No livro Pedagogia do Oprimido, a questão do diálogo foi posta como modo de inserir o educando no meio escolar sem impactos, pois esse participaria com as suas vivências que seriam trocadas entre educandos e educadores. Também no livro Paulo Freire: Uma Biobibliografia, definindo o diálogo como paradigma, ele nos diz que

para pôr o diálogo em prática, o educador não pode colocar-se na posição ingênua de quem se pretende detentor de todo o saber, deve, antes, colocar-se na posição humilde de quem sabe que não sabe tudo, reconhecendo que o analfabeto não é um homem perdido, fora da realidade, mas alguém que tem toda uma experiência de vida e por isso também é portador de um saber (Gadotti, 1999, p. 2).

Um dos Projetos de Ação, "Recursos tecnológicos e matemáticos no cotidiano dos jovens educandos", buscou inserir os educandos da EJA na intercessão entre o mundo tecnológico e o matemático. Nesse, identificou-se que a grande maioria dos jovens educandos da EJA, dos municípios estudados, apresentava dificuldades na utilização dos recursos tecnológicos e matemáticos referentes às atividades ligadas ao seu dia-a-dia. Para isso, foram utilizadas metodologias voltadas para o cotidiano do educando: partindo da observação, análise e reflexão, foram realizadas atividades práticas capazes de mobilizar e despertar o interesse para o uso dos recursos, com a intenção de desenvolver e ampliar a leitura de mundo exigida nas mais diversas situações das quais fazem parte os jovens educandos. O Projeto de Ação teve como intenções: ampliar o conhecimento tecnológico e matemático dos jovens educandos; sanar as possíveis dúvidas que concorrem para a não utilização desses recursos no cotidiano de cada sujeito; ampliar os contatos dos educandos com equipamentos tecnológicos, possibilitando uma visão alternativa de mundo. Ele promoveu o estímulo de todos os envolvidos para a construção de uma educação que leia e interprete a vida em todos os momentos.

\footnotetext{
${ }^{5}$ Control-C é um comando de atalho utilizado na maioria dos programas editores de texto modernos para copiar uma seleção de texto e/ou imagens para a área de transferência. Para mais informações, veja "Cortar, copiar e colar" na Wikipédia. Acessado em 18 nov. 2011. Disponível em: http://pt.wikipedia.org/wiki/Control-C ${ }^{6}$ Control-V é um caractere de controle que se dá em um teclado de computador, largamente utilizado como tecla de atalho para um comando de editor de texto muito comum: colar. Este comando permite transferir uma pequena ou média massa de dados contíguos: de trecho de textos até grandes arquivos (nota-se que existe um limite de dados que varia de acordo com a implementação feita pelo Sistema Operacional). Sua execução recupera os últimos dados salvos na área de transferência (Cortar, copiar e colar) e os insere no campo previamente selecionado. Acessado em 18.11.2011. Disponível em: http://pt.wikipedia.org/wiki/Control-V.
} 
A revolução dos meios de comunicação vem provocando mudanças significativas e definitivas nas sociedades. No entanto, é fato que existe ainda um grande número de pessoas que estão à margem desse processo. As que dispõem de recursos tecnológicos, como computador e linha telefônica, podem conectar-se à internet, ampliando enormemente suas possibilidades de acesso à informação. No entanto, é preciso considerar que, principalmente nos países subdesenvolvidos, onde há carência até de redes de energia elétrica, esgoto e água encanada, conectar-se à rede mundial de computadores é um direito que toma ares de privilégio por ser restrito a um pequeno grupo social. Em algumas das áreas periféricas dos municípios estudados, esse ainda é um quadro real.

A questão do analfabetismo é um dos grandes desafios sociais da atualidade. Em nosso país ainda contata-se a existência, dentre as pessoas com 15 anos ou mais de idade, de cerca de 15 milhões que não concluíram os Anos Iniciais do Ensino Fundamental, outras 33 milhões que não completaram os Anos Finais e outras 13 milhões que não acessaram ou concluíram o Ensino Médio. Ao todo, são mais de 60 milhões de brasileiros e brasileiras que não tiveram assegurado o seu direito constitucional à educação.

Contudo, esta importante demanda não tem sido historicamente atendida de modo adequado nas redes de ensino, tanto do ponto de vista quantitativo quanto qualitativo. Os dados do Censo Escolar demonstram que as redes têm atendido em torno de $9 \%$ dos jovens e adultos, sendo grande parte na etapa referente aos Anos Finais do Ensino Fundamental, a qual tem baixo índice de atendimento.

O Brasil é um dos países que vem há anos se debatendo com este problema. A busca de alternativas teóricas e metodológicas para que estes indivíduos deixem de fazer parte do contingente de analfabetos e passem a ser indivíduos com domínio do mundo letrado é uma questão central, uma vez que aqueles que não possuem esse domínio estão sendo cada vez mais excluídos

Uma coisa é certa: vivemos hoje em uma destas épocas limítrofes na qual toda a antiga ordem das representações e dos saberes oscila para dar lugar a imaginários, modos de conhecimento e estilos de regulação social ainda pouco estabilizados.

Vivemos um destes raros momentos em que, a partir de uma nova configuração técnica, quer dizer, de uma nova relação com o cosmos, um novo estilo de humanidade é inventado. (Lévy, 1993, p. 17).

Vivemos uma reconfiguração social a partir das mudanças que o desenvolvimento cada vez maior das técnicas traz para o nosso cotidiano. Esse novo contexto social - intitulado de Sociedade do Conhecimento ou de Sociedade da Informação (Castells, 1993) -, exige um perfil específico de indivíduo capaz de se incluir nesta nova configuração social. Quem não puder ficará à margem. Assim, vencer o analfabetismo digital passa a ser direito dos sujeitos educandos da EJA, em especial, daqueles que tratamos aqui, a saber, as juventudes presentes nessa modalidade de ensino.

Por pertencer a uma pluralidade de grupos, a juventude atual constrói, muitas vezes, experiências fragmentadas. O pertencimento a esses grupos e redes constitui uma forma de participação social. Falar das formas como os jovens pobres vivenciam sua condição e as situações que os marcam é falar também das redes que tecem e das formas como o fazem. É falar também das redes que não tecem, pois esse direito lhes é negado, muitas vezes. Saber de jovens que caminham quilômetros, diariamente, para acessar um computador e uma linha de internet pública; saber de jovens que trabalham com computadores e que não têm a permissão de seus patrões para acessá-los mesmo depois do horário; saber de jovens aos quais só é permitido, no espaço escolar, acessar sites relacionados aos conteúdos programáticos que estejam estudando; saber de jovens que compram ou trocam, por valores mínimos ou por favores, celulares sabidamente roubados, inclusive de outros jovens; saber de jovens que não têm garantido o direito de se conectar em rede com outros jovens pela falta da condição econômica e, finalmente, saber que quase a metade dos 549 (quinhentos e 
quarenta e nove) jovens presentes no Projeto que aqui relatamos se encontra nessa situação, dá-nos a justificativa necessária para tratar do tema neste artigo.

Apesar de ser um fator positivo para as sociedades que dispõem desses recursos tecnológicos, os mesmos vêm provocando alterações na forma como as pessoas lidam com as informações recebidas por esses meios. Isso, de certa forma, provoca um distanciamento dos sujeitos em relação à sua história pessoal e coletiva. Atualmente, as pessoas utilizam, por exemplo, a tecnologia, por meio do Sistema de Posicionamento Global - GPS , para se deslocar dentro de sua cidade. A facilidade promovida por essa tecnologia cria um processo negativo para a cultura, porque não leva em conta os marcos culturais de uma cidade. Essa, por sua vez, promove a orientação, tendo como referência comandos de voz que se limitam apenas a indicar caminhos. Assim, nomes de ruas e avenidas significativos para a construção da história social e da individualidade são descartados pelo equipamento.

Com o intuito de promover uma ação que valorize também outros movimentos, foram desenvolvidos projetos escolares que buscam a recuperação e a valorização de alguns bens e atividades culturais marcadamente presenciais. Os educadores de Matemática, Geografia, Português, História e Inglês desenvolveram oficinas com os jovens estudantes em todas as escolas que trabalham com EJA nos municípios participantes do Projeto.

\section{Praticando outra economia}

A ideia de um mundo sustentável em que não haja degradação ambiental, no qual a reciclagem se torne apenas mais uma rotina para as pessoas, com emissões de gases poluentes reduzidas a zero, ou pelo menos quase zero, é uma utopia? Para o coletivo de educadores que orientamos, não. Movimentos que busquem o desenvolvimento, através da educação ambiental, economia solidária e de ações governamentais vinculadas a políticas públicas, podem transformar o mundo utópico na realidade desejada. Nesse caso, um mundo sustentável, segundo os resultados do Projeto de Ação desenvolvido.

Segundo dados da $\mathrm{ONU}^{7}$, uma significativa parcela da população mundial viverá nos grandes centros urbanos no futuro. Diante disso, a gerência do meio urbano passa a ser o grande desafio ambiental desse século XXI, pois é nessa parte territorial que se concentram grandes instrumentos produtores de danos ambientais, como a poluição atmosférica, através das vias abarrotadas de veículos e dos escapamentos, das indústrias e das suas chaminés, a poluição sonora, que tira o sentimento de tranquilidade, a poluição visual, que cobre montanhas e ofusca monumentos de valor histórico, e o lixo, um dos grandes problemas das cidades em qualquer parte do mundo. Além disso, é no meio urbano que se concentram as grandes demandas por recursos naturais.

A tendência de agravamento dessa situação aumenta à medida que o número de pessoas que vivem nas cidades cresce de forma acelerada, gerando uma demanda ainda maior por recursos naturais. A redução da desigualdade social também é um fator preponderante para a aplicação da sustentabilidade. Este pode e deve contar com a contribuição da educação para além de programas de transferência de renda como ocorre em diversos países, incluindo o Brasil ${ }^{8}$. A desigualdade social, a má distribuição de renda, as condições precárias de trabalho e sobrevivência contrapõem diretamente os princípios da Economia Solidária que busca promover a valorização e bem-estar do ser humano, a qualidade de vida e consumo, partindo da integração e da solidariedade entre as

\footnotetext{
${ }^{7}$ Dados verificáveis em http://www.onu.org.br/cidades-al-caribe-2012/

${ }^{8}$ Programas de transferência condicionada de renda são políticas sociais empregadas no combate à pobreza. Estes programas têm como finalidade prover assistência, no curto prazo, para as famílias pobres. No Brasil, o governo federal desenvolve os Programas Brasil sem Miséria, Bolsa Família, Benefício de Prestação Continuada. Estudos aos quais tivemos acesso (Rocha, 2005; Soares, 2006) concluem que tais programas de transferência têm efeitos sobre a redução das desigualdades e da pobreza no País e destacam a importância deste tipo de política.
} 
pessoas em detrimento do capital. Além disso, as experiências de Economia Solidária ${ }^{9}$, que se projetam no espaço público, promovem a construção de um ambiente social que se pretende justo e sustentável.

Assim, os Projetos de Ação "Oficinas de culinária" e "Aquecedor solar: Fonte de energia alternativa", construídos coletivamente, tiveram como foco a busca pela sustentabilidade e valorização dos sujeitos envolvidos. O projeto "Oficinas de culinária” viabilizou, para os jovens da EJA dos municípios envolvidos, a oportunidade de participarem de oficinas de produção de doces dentro do espaço escolar. A atividade desenvolveu-se através de grupos de trabalho e teve como finalidade a geração de trabalho e renda coletiva, bem como a inclusão econômica desses jovens educandos e o respeito ao meio ambiente. Diferente do modo capitalista, que tem contribuído para a má distribuição de renda e estimulado as pessoas a demonstrarem condutas individualistas e competitivas, o projeto buscou mostrar, para os jovens educandos da EJA, que outra economia é possível, viável e interessante.

O projeto "Aquecedor solar: Fonte de energia alternativa" buscou desenvolver, junto aos jovens da EJA, uma nova forma de aprender a economizar energia no seu dia-a-dia - o que tem impacto também econômico. Para isso, o projeto propiciou a construção de um equipamento solar acessível a pessoas de menor renda. Buscou-se uma solução prática para os problemas do cotidiano, utilizando conhecimento científico atrelado às experiências dos próprios educandos, mediados por educadores de Biologia, Física, Química, Matemática, Geografia, História, Língua Portuguesa, Língua Inglesa e Educação Física, e utilizando, no trabalho empírico, os espaços escolares e das comunidades em todos os municípios envolvidos.

Nessa perspectiva, percebemos que a escola pode atuar como espaço de aprendizagem que contribui para a qualificação desses educandos jovens através das experiências propostas fora do padrão capitalista e dentro de perspectivas de trabalho que visam contribuir com a formação dos sujeitos, desenvolvimento pessoal, interação e cooperação. Percebeu-se, também, que a formação continuada e em serviço pode ser desenvolvida entre os educadores a partir da reflexão-açãoreflexão de suas práticas educativas junto aos educandos.

\section{Praticando Outras Culturas}

Atualmente, muitos educadores ainda encontram dificuldades para promover atividades culturais nos espaços educativos em que trabalham, ou para incentivar os educandos com os quais trabalham a frequentar espaços destinados para esse propósito. Várias razões - falta de estrutura para deslocamentos, pois não existem veículos para atender a EJA, espaços culturais que não atendem no horário noturno (quando a maioria das turmas de EJA funciona), elitização de alguns desses espaços, falta de apoio de outros colegas educadores, falta de planejamento das Secretarias Regionais de Ensino, que ainda não enxergam a EJA como prioridade - levam a vários desafios. Além dos problemas relacionados, temos a falta de conhecimento, por parte dos educadores e dos educandos, acerca do grande número de possibilidades de atividades culturais existentes. Isso acaba direcionando, em especial os jovens da EJA, a participar de programas que pouco contribuem para promover a cultura de sua cidade ou de seu país.

Dessas situações descritas resultam desafios à prática pedagógica que estabelecem relação direta com a atualidade mundial reveladora de nosso modelo econômico-social - uma cultura massificada que dita modos de vida, modos de consumo, e que silencia as especificidades dos sujeitos. Cabe, aqui, ressaltar que entendemos a educação como um caminho de mão dupla por onde trafegam educadores e educandos em busca de realizações pessoais e profissionais, e que a atividade cultural está intimamente ligada ao conhecimento e à forma como esses sujeitos leem o mundo.

${ }_{9}^{9}$ Dados verificáveis em http://www.fbes.org.br/ 
Observa-se que os jovens pobres são privados de acessos e têm seus direitos negados, portanto, não têm alternativas ou possibilidades colocadas à disposição de outros jovens, de outros grupos. Eles e elas não deixam de fazer porque querem. São impedidos de fazer, muitas vezes, o que realmente querem. Retomamos Gatti (2006), por considerar profundamente elucidador o ponto de vista daquela educadora.

Sobre este ponto gostaria de comentar que leituras, confronto de autores, dúvidas sobre afirmações ou modelos e conclusões de pesquisa, questões dos limites impostos por conceitos e metodologias, no contraponto com o próprio contato vivência - do pesquisador com a área, e, no caso de áreas mais aplicadas, ligadas a profissões, no contraponto mesmo da experiência cotidiana do trabalho no qual se gera um conhecimento específico é que se criam as condições que permitem o desenvolvimento de uma perspectiva crítica dos autores, ao mesmo tempo em que consistente com os problemas que se propõem examinar. A partir dessa base é que os pesquisadores têm condições de desencadear análises e inferências, caso contrário fica-se no óbvio ou no senso comum. Este trabalho de construção de referentes quase não é observado na produção da pesquisa em educação. (Gatti, 2006, p. 07). ${ }^{10}$ Citamos, como fiz na tese de doutoramento (Da Silva, 2007c), a manifestação de uma jovem educanda que protesta quanto à ausência de oportunidades, de possibilidades e de disponibilidades, enfim, quanto à negação do acesso aos direitos:

Ruanda: Eu não quero aprender a fazer balaio de jornal velho. Eu não quero fazer "negócio" de colocar planta de fundo de garrafa pet que ninguém compra prá usar, só mesmo de pena da gente. Eu quero aprender a pintar quadro que as pessoas comprem com vontade prá colocar na parede. Com meu nome assinado. Eu não quero aprender a pixar, é ... a grafitar. Quero saber o nome do tipo do quadro que eu já vi numa loja e que eu acho lindo. Se eu te mostrar você me fala como chama aquilo?

Eu: Se eu souber falo e se eu não souber a gente procura alguém que nos ajude a entender de arte. Eu entendo muito pouco disso.

Ruanda: Por que que eu não posso aprender a ser pintora? Por que eu sou pobre? Diz que tem que nascer com o dom. Mas quem disse que eu não nasci? Quem disse que eu não posso aprender na "aula de ter dom"? Tem uma porrada de artista da televisão que aprenderam a ser artistas. Eu vi que até prá ser palhaço tem curso. Não é todo engraçadinho que vira palhaço.

Gabão: Se não aqui ia ser cheio deles rsrsrsrsrsrsrs.

Todos: rsrsrsrsrsrsrsrssrs

Ruanda: Eu quero muito ser pintora de quadro. Quero mesmo!!! Mas aqui nos projetos só tem negócio de planta de garrafa pet, folha de papel reciclado, uma galinha com jornal velho prá botar ovo dentro e um porta retrato de jornal torcido. Na escola também nem se fala do "meu quadro". A aula de artes... bom... humf! Deixa quieto!

Percebemos que a noção de educação, de cultura e de trabalho dessa jovem denota maior alargamento que algumas políticas de juventude propostas por gestores públicos, pois ela trabalha com a visão do direito que tem de vivenciar sua condição juvenil, sem perpetuar sua situação de exclusão. Acesso ao trabalho é direito e, quando tratado como tal, pressupõe que o viés empobrecedor da formação humana esteja ausente de sua prática. (Da Silva, 2007c, p. 179).

\footnotetext{
10 Sugerimos a leitura do artigo na íntegra em http://www.lite.fae.unicamp.br/revista/gatti1.pdf
} 
Como cobrar uma participação cidadã, crítica e consciente dos sujeitos da EJA quando não trabalhamos com eles outras possibilidades de ler e interpretar o mundo que entra, ou melhor, invade nossas casas através dos meios de comunicação de massa? Como criticar essa ou aquela música, se não ofertamos uma possibilidade diferente e nem travamos uma interlocução com as criticadas? E ainda: como o educador pode propor essas outras possibilidades se ele mesmo não as conhece? Missão quase impossível! Quase impossível. Aqui, em específico, essa missão ficou possível nos Projetos de Ação: "As Juventudes da EJA nos Espaços Urbanos", "Assombração, um assunto tremendo", "Conhecendo nossa cidade", "Relação de pertencimento dos educandos jovens com o município de Sabará" e "Conhecendo Nova Lima".

Esses projetos tiveram como eixo norteador o processo de aprendizagem em diálogo com as manifestações culturais dentro e fora dos espaços escolares. Reapresentar a esses jovens as cidades onde vivem, os espaços que essas cidades têm e que são seus por direito - espaços públicos - e seus diversos usos, assim como escutar desses jovens o que eles gostariam de conhecer e possibilitar esse desejo, impulsionaram educadores e educandos, de uma forma ousada, a "sair do espaço escolar", compreendido até aquele momento como único lugar de aprendizagem, vivenciando outros jeitos de olhar e sentir tais lugares. Eles foram instados a repensar a prova de papel e o lápis como únicos instrumentos de avaliação possíveis, a afirmar que há aprendizagens de que somente o papel e o lápis não dão conta, porque elas são para a vida e serão significadas pelos educandos quando as formas de organização do pensamento que estão sendo mobilizadas, nas atividades em sala de aula, adquirirem sentido associado a todos os momentos da vida desses cidadãos e cidadãs.

Paulo Freire (1987) ajuda nesta problematização quando provoca a considerar como tarefa nossa a assunção a uma postura de busca de outras relações possíveis em nossa prática pedagógica, a saber:

O grande problema está em como poderão os oprimidos, que "hospedam" o opressor em si, participar da elaboração, como seres duplos, inautênticos, da pedagogia de sua libertação. Somente na medida em que se descubram "hospedeiros" do opressor poderão contribuir para o partejamento de sua pedagogia libertadora. Enquanto vivem a dualidade enquanto ser é parecer, e parecer é parecer com o opressor, é impossível fazê-lo. (Freire, 1987, p. 32).

Enfim, propor práticas pedagógicas que desafiem o óbvio, que atendam a uma nova demanda que se apresenta na EJA, motivaram a escrita, a execução desses Projetos de Ação. Foi possível desmitificar o que a sociedade como um todo, incluindo a escola, pensa da cultura dos jovens educandos da EJA. ${ }^{11}$

Foi possível aos educandos mostrar o que eles pensam e sabem sobre determinados espaços, o que pensam e sabem sobre determinadas atividades, o que eles esperam da escola, dos educadores e dos educandos adultos e idosos, como nos revelou um dos educandos participante de um dos Projetos de Ação que, expressou, de maneira bastante contundente que "Foi na aula de História que eu fiquei sabendo onde fica o teatro, o cinema sem ser o do shopping, lugar pra dançar e ouvir música de grátis". Ou, como nos disse outro: "Eu não sabia que tinha lugares de deixar o currículo prá procurar emprego. Foi no Projeto que eu aprendi onde é e como chegar lá". Ou, ainda, "o que eu achei mais legal é que em outros projetos não perguntam pra gente o que a gente quer antes de fazer igual foi nesse. Eu ajudei a fazer o projeto".

\footnotetext{
${ }^{11}$ Para aprofundamento quanto à cultura juvenil sugerimos a leitura de Reguillo (1995; 2000); Green e Bigun (1995); Ibase/Polis (2005); Margulis e Urresti (1996); Melucci (2001; 2004); Pais (2003; 2006) e Ribeiro (2004).
} 
Foi possível aos educadores perceber como atividades diferenciadas são repletas de significados para eles. E, em especial, como a estima desses sujeitos muda ao perceber que são cidadãos de direito, que são respeitados, que suas opiniões são ouvidas e consideradas, que outras vivências são possíveis, urgentes e necessárias.

Assim, são ações que buscam estabelecer vínculos e relações de pertencimento da juventude com a escola, transformando a instituição em um ambiente prazeroso e comprometedor para o jovem, estruturando as relações e os contratos de convivência no espaço escolar. É a prática que entende e acredita que todos os jovens podem aprender, que todos eles sabem alguma coisa, e que cada sujeito é responsável pela sua construção do conhecimento e pela ressignificação dada a esse conhecimento, pois, em síntese, lembrando Paulo Freire (1995), os jovens só aprendem quando têm um projeto de vida em que o conhecimento é significativo para eles. Mas,

é o sujeito quem aprende através de sua própria ação transformadora sobre o mundo. [...] O educador deve ensinar. É preciso fazê-lo. Só que ensinar não é transmitir conhecimento. Para que o ato de ensinar se constitua como tal, é preciso que o ato de aprender seja precedido do, ou concomitante ao, ato de apreender o conteúdo ou o objeto cognoscível, com que o educando se torna produtor também do conhecimento que lhe foi ensinado (Freire, 1995, p. 188). Nessa perspectiva, uma leitura possível é a de que, para os jovens educandos que participaram conosco dos Projetos de Ação, tal prática se constituiu numa "aula diferente", ou seja, numa prática pedagógica pensada como mediadora de recuperação da auto-estima, restabelecedora da confiança, do diálogo e do comprometimento dos diferentes sujeitos com o projeto político-pedagógico e possibilitadora da construção do conhecimento.

\section{Socilizando resultados}

Os projetos analisados neste artigo foram realizados em 2010 e 2011, com a participação de jovens educandos da EJA cuja faixa etária se situa entre 15 e 29 anos de idade, em disciplina cursada por seus professores durante a realização do Curso de Pós-Graduação Lato Sensu Especialização em Docência da EJA na Educação Básica: Juventudes Presentes na EJA, por dois semestres letivos. Jovens e educadores frequentam e trabalham em escolas municipais mineiras.

Desses projetos resultaram práticas pedagógicas a partir das quais tanto educadores quanto estudantes foram desafiados a construir e desenvolver conhecimentos diversificados relacionados ao cotidiano dos jovens educandos que participam do processo de alfabetização ou de etapas posteriores a ele no Ensino Fundamental e no Ensino Médio. A maior parte da reflexão constituída com os cursistas sobre tais trabalhos foi guiada pela prática docente de cada educador em diálogo com as ações dos demais cursistas e com a bibliografia estudada. Ressaltamos que, durante o Curso, foram trabalhadas disciplinas focadas especificamente no campo temático da EJA e no campo temático das Juventudes. Assim, para a produção dos Projetos de Ação, focamos uma bibliografia que tratou da produção de projetos. ${ }^{12}$ Todo o processo desenvolvido emerge como parte essencial

\footnotetext{
${ }^{12}$ Quando falamos sobre a perspectiva interdisciplinar em que nos apoiamos para a produção dos Projetos de Ação e, mais especificamente, deste artigo, é preciso fazer referência aos vários autores de que nos subsidiamos: Alves-Mazzotti (2003); Brasil (2001); Charlot (2000); Costa (2002a; 2002b; 2002c); Da Silva (2001; 2002; 2007a; 2007b; 2007c; 2007d; 2007e; 2008; 2009); Dalton (1996); Dossie Juventude e Educação (2004); Fazenda (1979); Fonseca (1999); Freire (2000); Freitas (1995); Gadotti (1993; 2006); Gatti (2002; 2004; 2005; 2006); Gil (1987); Giroux (1997); Goldenberg (1997); Ibge (1999); Martins (2009); Oliveira (1999); Ribeiro (1997); Rios (1982; 1988); Santos (1995); Saviani (1980; 1994); Severino (1993); Silva e Silveira (2007); Szymansky (2002); Thiollent (1985); Triviños (1987); Vóvio (2007); Yin (2005) e Zago, Carvalho e Vilela (2003). Além dos links que se seguem:
} 
de uma abordagem de ensino interativa e dialógica, buscando enfatizar situações econômicas, tecnológicas e culturais dos educandos.

Ao ler e confrontar os projetos de intervenção, constatou-se que todos tiveram a intenção de promover aprendizagens para além da sala de aula. Eles visaram contribuir para que os jovens percebessem a importância de realizar atividades em grupo, formando equipes de estudos, aplicando o apr(e)endido nas oficinas de trabalho, tanto na construção, produção e uso dos recursos tecnológicos como na da economia solidária. Ademais, buscaram promover vivências de apropriação pelos jovens educandos dos bens culturais que os municípios e o estado oferecem com a consequente tomada de consciência de que este acesso é direito de todos.

Ficou explicitado, no processo de análise dos projetos, que todos intentaram realizar um trabalho significativo, porque capaz de chamar a atenção desses jovens, promovendo uma relação de diálogo entre as disciplinas, buscando maior interação e enriquecendo o currículo da EJA com atividades expressivas. Atividades que fizessem com que os educandos se interessassem mais pelas atividades escolares e se sentissem pertencentes e corresponsáveis por aprendizagens que se efetuam quando o processo de construção é feito com a participação desses educandos em todas as etapas do trabalho: desde a apresentação do que se pretende fazer, passando pela avaliação do processo, até seu resultado final.

Como é possível observar a partir da nota explicativa acerca da bibliografia estudada, um dos conceitos sobre os quais tratamos foi o da interdisciplinaridade na construção dos Projetos de Ação. Entendemos ser adequado aderir à concepção que a compreende como resposta a uma necessidade nos campos das ciências humanas e da educação para superar a fragmentação e o caráter de especialização do conhecimento, consequências de uma epistemologia de tendência positivista em cujas raízes estão o empirismo, o naturalismo e o mecanicismo científico do início da modernidade (Gadotti, 2006). Por caracterizar-se como um movimento contemporâneo pautado na perspectiva da dialogicidade, busca romper com o caráter de hiperespecialização e com a fragmentação dos saberes. Assim, optamos pelo trabalho interdisciplinar, caracterizado pela interação de modelos e conceitos complementares, de material analítico e de metodologia, com ações interprofissionais e interinstitucionais, com consistência teórica e operacional que permitisse a estruturação das diversas ações propostas num curso que se propôs abrangente.

Outra finalidade dos projetos foi a elaboração e implementação de práticas mais flexíveis, diversificadas e participativas no currículo da EJA. Práticas curriculares que foram definidas a partir das necessidades e interesses dos jovens, de modo a levar em consideração suas realidades sociocultural, científica e tecnológica e reconhecer seu saber, possibilitando a constituição de uma cultura de questionamento nos espaços sociais e educacionais e contando com mecanismos de reconhecimento da validade das experiências.

O desenvolvimento dos Projetos e as relações identificadas entre eles, a partir de princípios e objetivos compartilhados, demonstraram como é fundamental o diálogo entre educandos e educadores nas diversas práticas protagonizadas dentro e fora da sala de aula, isto é, em qualquer espaço educativo. No decorrer do desenvolvimento dos Projetos, surgiram necessidades de inserir, nessas atividades, o estudo de conceitos, teorias e práticas científicas, utilizando estratégias distintas, mas sempre baseadas no diálogo, para que os educandos não perdessem o interesse pelas atividades. Destas vivências resultaram duas conclusões: a necessidade de dialogicidade em toda e qualquer prática e a tarefa docente de garantir o acesso ao conhecimento mais sistematizado por parte dos

http://www.comoeconomizardinheiro.com.br/energia/aquecedor+solar+caseiro.html. Acesso em 18 set. 2011. http://www.dambiental.com.br/downloads/downloads asbc.pdf. Acesso em 18 set. 2011. http://www.escolher-econstruir.eng.br/Dicas/DicasI/Kwatt/pag1.htm. Acesso em 18 set. 2011.

http://www.sociedadedosol.org.br/asbc/asbc online.htm. 
educandos, uma vez que deixar de partilhar com eles saberes construídos e reconhecidos, científica e socialmente, constitui, a nosso ver, mais uma forma de negar acesso a conhecimentos importantes e valorizados em nossa sociedade.

Quanto às avaliações das atividades propostas em cada um dos Projetos, concluímos que a aceitação dos educandos foi satisfatória. Durante os dois bimestres de aplicação dos Projetos de Ação nas 23 escolas participantes, foram constatadas a ausência de abandonos temporários e uma redução de 37\% no número de faltas esporádicas. No entanto, todos os Projetos se depararam com elementos complicadores como: custo, uma vez que não tínhamos parceiros para o financiamento dos Projetos de Ação; indisponibilidade do educador, uma vez que, recorrentemente, gestores educacionais se recusavam a permitir a junção de turmas ou a saída do educador para a aplicação do Projeto; comodismo, uma vez que alguns colegas dos educadores envolvidos não se dispuseram a colaborar, alegando insucesso da iniciativa; responsabilidade de sair com alunos com idade inferior a 18 anos e programação dos locais a serem visitados, uma vez que essa preparação ficou toda ao encargo dos educadores que concordaram em se envolver e dos cursistas, seus colegas de trabalho. Entretanto, em lugar de esmorecer os ânimos de educadores e educandos, tais dificuldades os impulsionaram mais ainda.

\section{Considerações Finais}

No contexto social brasileiro, a EJA ainda é um grande desafio. Parte significativa da população não conseguiu acessar o direito básico à Educação, garantido pela Constituição Brasileira. Em muitos casos, quando conseguiu o acesso, não teve a permanência garantida por motivos diversos. Em outras situações, garantiu-se o acesso e a permanência, mas a aprendizagem não se efetivou. A superação do desafio de garantir que a EJA efetive o tripé do direito (ao acesso, à permanência e à efetiva aprendizagem) exige que sociedade civil e governos unam forças, uma vez que se trata de sujeitos que fazem parte da Classe Trabalhadora. Os educandos da EJA são trabalhadores, pobres, jovens, subempregados, excluídos, mas que estão, pouco a pouco, garantindo o seu espaço na escola.

Assim, espera-se que essa permanência esteja atrelada ao sucesso, à sensação de pertencimento a uma escola que reconhece seus conhecimentos e é capaz de auxiliá-lo na busca de outros, ao trabalho prático e diário dos educadores. Espera-se que este artigo traga contribuições possíveis para uma reflexão sobre esse cenário. As juventudes presentes na EJA apresentam especificidades e são caracterizadas pela diversidade. São sujeitos que compartilham ideias, anseios, angústias, planos futuros, experiências, são sujeitos que acessam bens tecnológicos e de consumo, e estão cada vez mais unidos de acordo com as identidades que trazem consigo e suas experiências de vida. É desejável que o espaço escolar e, em especial, a EJA considerem tais características, para que não se silenciem, mais uma vez, esses sujeitos de direitos. Observamos que, quando em sua prática o educador tem um olhar para a diversidade do educando, esse se revela. Essas observações estão pautadas nos relatos e nas considerações dos nove projetos que constituíram base para este artigo.

A reflexão analítica sobre a ação educativa tratada neste artigo é fruto de um trabalho de "compilamento" de projetos desenvolvidos em um Curso de Especialização com enfoque nas “juventudes presentes na EJA”. Esse esforço é submetido a uma abordagem teórica e metodológica libertadora, segundo princípios buscados, sobretudo, em Paulo Freire, o que lhe confere rigor e qualidade acadêmica. Observou-se, na prática cotidiana, o diálogo entre os projetos relatados em interface com uma fundamentação teórica capaz de explicitar avanços teórico-epistêmicos para o campo da Educação de Jovens e Adultos.

A proposta desse Curso mostrou-se audaciosa e inovadora, desde o seu início, ainda que não soubéssemos o tamanho do desafio. Evidenciou-se a urgência e a importância que tem o processo 
formativo no cotidiano do educador da EJA. Acreditamos que as mudanças nas nossas práticas, nesse período de aplicação de projetos de intervenção, fortaleceram a EJA nas escolas em que foram aplicados. Esse fortalecimento fica evidenciado pela satisfação e mudança de postura dos educandos, em especial dos jovens. Outro ponto a ser destacado é o movimento que esse Curso de Especialização gerou dentro das escolas e, em alguns momentos, nas Secretarias de Educação dos municípios parceiros. Cumpre, assim, compreender que a educação para todos não é mais um ideal ao qual devemos pretender chegar um dia, pois o processo já se encontra em andamento e, espera-se, talvez possa se instituir como Política de Estado.

\section{Referências}

Abramo, H.. (2005) Condição juvenil no Brasil contemporâneo. In: Abramo, H.; Branco, P.P.M. Retratos da juventude brasileira: análises de uma pesquisa nacional. São Paulo: Instituto Cidadania; Fundação Perseu Abramo. p. 37-73.

Abrantes, P.. (2003) Os sentidos da escola: identidades juvenis e dinâmicas de escolaridade. Oeiras: Celta.

Alves-Mazzotti, A.J.. Impacto da pesquisa educacional sobre as práticas escolares.(2003) In: Zago, N.; Carvalho, M.P.; Vilela, R.A.T. (orgs.). (2003) Itinerários de pesquisa: perspectivas qualitativas em Sociologia da Educação. Rio de Janeiro: DPA. p. 33-48.

Andrade, E.R.. (2004) Os sujeitos educandos na EJA. TV Escola - Salto para o Futuro. Educação de Jovens e Adultos: continuar e aprender por toda a vida. Boletim, 20 a 29 set.

Brasil. (2000) Parecer CNE/CEB n. 11/2000. Diretrizeses Curriculares Nacionais para a Educação de Jovens e Adultos. Brasília: MEC.

Brunel, C.. (2008) Jovens cada vez. mais jovens na educação de jovens e adultos. Porto Alegre: Mediação.

Candau, V.M. (org.). (1999) A Didática em Questão. 17ª ed. Petrópolis: Vozes.

Castells, M. (1993) A Sociedade em rede. São Paulo: Paz e Terra.

Charlot, B.. (2000)Da relação com o saber. Elementos para uma teoria. Porto Alegre: Artes Médicas.

Da Silva, A.J.. (2001) Pedagogia de projetos: do desejo à prática. Revista Linha Direta. Belo Horizonte: In Foco Design Ltda, ano 4, n. 44, p. 10-11, nov.

Da Silva, A.J.. (2007a) A Formação Inicial e Continuada dos Professores de Adolescentes: os adolescentes existem?. Revista Diálogo Educacional (PUCPR), v. 07, p. 199-212.

Da Silva, A.J.. (2007b) Didática da Partilha de Saberes com Jovens: Um Estudo a Partir dos Significados Atribuídos por Estudantes às Práticas Pedagógicas Inovadoras de seus Professores. Reunião Anual da Anped, 2007, Caxambu. 30ª Reunião Anual da Anped. Rio de Janeiro: Anped.

Da Silva, A.J.. (2008) Didática e Juventude: Um Estudo a Partir dos Significados Atribuídos por Estudantes às Práticas Pedagógicas Inovadoras de seus Professores. XIV Endipe, Porto Alegre.

Da Silva, A.J.. (2007c) Jovens Estudantes Pobres: Significados atribuídos às práticas denominadas inovadoras por seus professores. (Tese de Doutoramento).

Da Silva, A.J.. (2007e) Jovens Querem Mudar Quadro da Educação. O Ponto, Belo Horizonte, p. 0809, 01 mai.

Da Silva, A.J.. (2007d) Juventude e Partilha de Saberes na Escola Pública. Outro Olhar, Belo Horizonte, p. 04-09, 01 nov.

Da Silva, A.J.. (2009) A formação inicial dos professores de adolescentes: os adolescentes existem na EJA?. Paidéia: Revista do Curso de Pedagogia da Faculdade de Ciências Humanas e Sociais, Belo Horizonte: Universidade Fumec; Belo Horizonte: Faculdade de Ciências Humanas e Sociais, n. 7, p. 39-59, julho/dez. 
Da Silva, A.J.. (2002) Relações entre formadores, professores e adolescentes: de objetos no labirinto a sujeitos da educação. Dissertação (Mestrado) - Universidade Federal de Minas Gerais, Faculdade de Educação. Belo Horizonte.

Dalton, M.. (1996) O currículo de Hollywood: quem é o bom professor, quem é a boa professora. Educação e Realidade, v. 21(1), p. 97.

Dayrell, J.. (2001) Múltiplos olhares sobre educação e cultura. Belo Horizonte: Editora UFMG.

Dayrell, J.. (2003) O jovem como sujeito social. Revista Brasileira de Educação, nº 24, São Paulo.

Dossie Juventude e Educação. (2004) Perspectiva. Revista do Centro de Ciências da Educação. Vol 22, n. 2 - julho/dezembro - Florianópolis.

Fazenda, I.C. (1979) Integração e interdisciplinaridade no ensino brasileiro: efetividade ou ideologia. São Paulo: Loyola.

Fonseca, C. (1999) Quando cada caso não é um caso: pesquisa etnográfica e educação. Revista Brasileira de Educação, n.10, jan/fev/mar/abr., p.58-78.

Freire, P.. (1980) Conscientização: Teoria e prática da libertação. São Paulo: Moraes.

Freire, P.. (1998) Pedagogia da autonomia. Saberes necessários à prática educativa. Rio de Janeiro: Paz e Terra.

Freire, P.. (2000) Pedagogia da esperança. 7. ed. Rio de Janeiro,RJ: Paz e Terra.

Freire, P.. (2002) Pedagogia da indignação: cartas pedagógicas e outros escritos. 1.ed. São Paulo: Editora UNESP.

Freire, P.. (1987) Pedagogia do Oprimido, 17ª ed. Rio de Janeiro, Paz e Terra.

Freire, P.. (1995) Professora sim, tia não: cartas a quem ousa ensinar. 6. ed. São Paulo, Olho d'Água.

Freitas, L.C.. (1995) Crítica da organização do trabalho pedagógico e da didática. Campinas: Papirus.

Gadotti, M.. (1999) Convite à leitura de Paulo Freire. São Paulo: Scipione.

Gadotti, M.. (1993) A organização do trabalho na escola: alguns pressupostos. São Paulo: Ática.

Gadotti, M.. (2006) Escola Cidadã. 11. ed. São Paulo: Cortez. 120p. (Coleção Questões da Nossa Época, v. 24).

Gatti, B.. (2006) Pesquisar em educação: considerações sobre alguns pontos-chave. Revista Diálogo Educacional. Curitiba, v. 6, n. 19, set./dez.

Gatti, B.. (2002) A construção da pesquisa em educação no Brasil. Brasília: Editora Plano. 86 p.

Gatti, B.. (2004) Estudos quantitativos em educação. Educação e Pesquisa, v. 30, n. 1, jan./abr., p. 11 30.

Gatti, B.. (2005) Grupo focal nas ciências sociais e humanas. São Paulo: Líber Livros.

Gil, A.C.. (1987) Como elaborar projetos de pesquisa. São Paulo: Atlas.

Giroux, H.. (1997) Os professores como intelectuais - rumo a uma pedagogia crítica da aprendizagem. Porto Alegre: Artes Médicas.

Goldenberg, M.. (1997) A arte de pesquisar. como fazer pesquisa qualitativa em ciências sociais. Rio de Janeiro: Record.

Green, B.; Bigun, C.. (1995) Alienígenas em sala de aula. In: Silva, T.T. (org.). Alienígenas em sala de aula: uma introdução aos estudos culturais em educação. Petrópolis/RJ: Vozes.

Hobsbawn, E.. (2004) A Era dos Extremos. São Paulo: Companhia das Letras.

Ibase/Polis. (2005) Juventude Brasileira e Democracia: participação, esferas e políticas públicas. Rio de Janeiro: Ibase/Polis, Relatório Final de pesquisa, 2005.

Ibge. (1999) População jovem no Brasil. Rio de Janeiro: IBGE/Departamento de População e indicadores sociais. Rio de Janeiro: IBGE.

Kehl, M.R.. A juventude como sintoma da cultura. In: Novaes, R., \& Vannuchi, P. (orgs.). Juventude e Sociedade: Trabalho, Educação, Cultura e Participação. São Paulo: Fundação Perseu Abramo. p. 89-114. 
Lévy, P.. (1993) As tecnologias da inteligência: o futuro do pensamento na era da informática. Tradução de Carlos Irineu da Costa. São Paulo: Editora 34.

Margulis, M.; Urresti, M.. (1996) La juventud es más que una palabra. In: Margulis, M. (edit.) La juventud es más que una palabra. Buenos Aires: Biblos. p. 13-31. (Estudios Sociales).

Martins, C.H.S.; Carrano, P.C.R.. (2011) A escola diante das culturas juvenis: reconhecer para dialogar. Educação, v. 36, n. 1, 43-56, jan/abr. Santa Maria.

Martins, J.S.. (2009) Exclusão social e a nova desigualdade. 4. ed. São Paulo: Paulus. v. 1. 142 p.

Melucci, A.. (2001) A Invenção do Presente: movimentos sociais nas sociedades complexas. Petrópolis/RJ: Vozes.

Melucci, A.. (2004) O jogo do eu: a mudança de si em uma sociedade global. São Leopoldo/RS: Edt. Unisinos.

Mileto, L.F.M.. (2009) “No mesmo barco, dando força, um ajuda o outro a não desistir” - Estratégias e trajetórias de permanência na Educação de Jovens e Adultos. Universidade Federal Fluminense. Niterói. .

Oliveira, M.K.. (1999) Jovens e adultos como sujeitos de conhecimento e aprendizagem. Revista Brasileira de Educação. n. 12. São Paulo: ANPED - Associação Nacional de Pesquisa e Pósgraduação em Educação. p.59-73.

Pais, J.M.. (2006) Buscas de si: expressividades e identidades juvenis. In: Almeida, M.I.M.; Eugenio, F. (orgs.). Culturas jovens: novos mapas do afeto. Rio de Janeiro: Jorge Zahar.

Pais, J.M.. (2003) Ganchos, tachos e biscates: jovens, trabalho e futuro. Porto: AMBAR.

Peregrino, M.D.; Carrano, P.C.R.. (2003) Jovens e escola: compartilhando territórios e sentidos de presença. Revista de Estudios sobre la Juventud, São Paulo, v. 1.

Reguillo, R.. (2000) Emergência de culturas juveniles: Estrategias del desencanto. 1a Bogotá: Grupo Editorial Norma. $182 \mathrm{p}$.

Reguillo, R.. (1995)En la calle otra ver: las bandas - identidad urbana y usos de la comunicación. Guadalajara: Iteso.

Ribeiro, E.A.. (2004) A educação de jovens e adultos e os jovens do "último turno": produzindo outsiders. Faculdade de Educação da UFF/Eliane Ribeiro Andrade. - Niterói. Tese de doutorado. 228p.

Ribeiro, V.M.M. (coord.) (1997) Educação de Jovens e Adultos: proposta curricular para o $1^{\circ}$. segmento do ensino fundamental. São Paulo: Ação Educativa; Brasília: MEC.

Rios, T.A.. (1982) 0 caminho do educador. São Paulo, CENAFOR. (Seminário Sobre Avaliação Educacional)

Rios, T.A.. (1988) Educação ética e política - Reflexão sobre a noção de competência na prática educativa. São Paulo. PUC. Tese (Doutorado).

Rocha, S.. (2005) Impacto sobre a pobreza dos novos programas federais de transferência de renda. Revista Economia Contemporânea, v. 9, n. 1, p. 153-185, jan./abr.

Santos, B.S.. (1995) Um discurso sobre as ciências. Porto: Edições Afrontamento.

Saviani, D.. (1980) Educação: do senso comum à consciência filosófica. São Paulo: Cortez/Autores Associados.

Saviani, N.. (1994) Saber Escolar, currículos e didática, problemas da unidade conteúdo/método no processo pedagógico. Campinas: Autores Associados.

Severino, A.J.. (1993) Metodologia do trabalho cientifico. São Paulo: Cortez.

Silva, J.M.; Silveira, E.S.. (2007) Apresentação de trabalhos acadêmicos: normas e técnicas. Petrópolis: Vozes.

Soares, S.S.D.. (2006) Distribuição de renda no Brasil de 1976 a 2004 com ênfase no periodo entre 2001 e 2004. Brasília: IPEA. (Texto para discussão, n.1 166) Disponível em: <http://www.ipea.gov.br/pub/td/2006/td_1166.pdf>. Acesso em: 13/01/2013. 
Sposito, M.P.. (coord) (2009) O Estado da Arte sobre juventude na pós-graduação brasileira: Educação, Ciências Sociais e Serviço Social (1999-2006). Belo Horizonte: ARGVMENTVM. Volumes I e II.

Sposito, M.P.. Considerações em torno do conhecimento sobre juventude na área de educação. In: Sposito, M.P.. (Coord.). (2002) Juventude e escolarização: 1980-1998. Brasília: MEC/Inep/Comped. p.7-26.

Sposito, M.P.. (1997) Estudos sobre juventude em educação. Revista Brasileira de Educação. Mai/Jun/Jul/Ago, n. . 5, Set/Out/Nov/Dez, nº 6, Número especial.

Sposito, M.P.; Carrano, P.C.R.. (2003) Juventude e políticas públicas no Brasil. Revista Brasileira de Educação, Rio de Janeiro, n. 24, dezembro, p.37-52.

Szymansky, H. (org.). (2002) A entrevista na pesquisa em educação: a prática reflexiva. Brasília: Editora Plano. 86 p.

Thiollent, M.. (1985) Metodologia da pesquisa-ação. São Paulo: Cortez.

Triviños, A. (1987) Introdução à pesquisa em Ciências Sociais: a pesquisa qualitativa em educação. São Paulo: Atlas.

Veiga, I.P.A.. (2011) Repensando a Didática. 29. ed. Campinas: Papirus.

Vóvio, C.. (2007) Práticas de leitura na EJA: do que estamos falando e o que estamos aprendendo. REVEJA, Belo Horizonte, Vol. 1, n. 0, Agosto.

Yin, R.. (2005) Estudo de caso. 3. ed. Porto Alegre: Bookman.

Zago, N.; Carvalho, M.P.; Vilela, R.A.T. (orgs.). (2003) Itinerários de pesquisa: perspectivas qualitativas em Sociologia da Educação. Rio de Janeiro: DPA.

\section{Documentos on-line:}

http://www.abnt.org.br/

http:/ / www.abpn.org.br/copene/index.php?option=com content\&view=article\&id=92\&Itemid=6

$\underline{5 \& l a n g=p t}$

http://www.comoeconomizardinheiro.com.br/energia/aquecedor+solar+caseiro.html. Acesso em 18 set. 2011.

http://www.dambiental.com.br/downloads/downloads asbc.pdf. Acesso em 18 set. 2011.

http://www.escolher-e-construir.eng.br/Dicas/DicasI/Kwatt/pag1.htm. Acesso em 18 set. 2011. http://www.sociedadedosol.org.br/asbc/asbc online.htm. Acesso em 18 set. 2011. 


\section{Sobre a Autora}

\section{Analise de Jesus da Silva}

Universidade Federal de Minas Gerais (UFMG) - Brasil

Doutora em Educação pela UFMG. Professora Adjunta do Departamento de Métodos e

Técnicas de Ensino (DMTE) da FAE-UFMG. Coordenadora do Núcleo de Educação de Jovens e Adultos - NEJA/FAE/UFMG. Coordenadora Geral do Curso de Pós-Graduação Lato Sensu Especialização em Docência da EJA na Educação Básica Especificidade Juventudes presentes na EJA. Coordenadora Pedagógica do Curso de Aperfeiçoamento ECOSOLEJA -

NESTH/FAFICH/UFMG. Professora do Curso de Pós-Graduação Lato Sensu Especialização em Docência na Educação Básica, Juventude e Escola. Professora Formadora da UAB/UFMG. Professora Orientadora da Escola de Gestores. Coordenadora do Sistema de Monitoramento e Avaliação do PROJOVEM URBANO no Centro-Oeste, Minas Gerais, Espírito Santo e Tocantis pelo GAME/FAE/UFMG. Coordenadora dos Fóruns Mineiro e Metropolitano de Educação de Jovens e Adultos. Assessora e Consultora Pedagógica. Assessora do Projeto EJA no ENSINO MÉDIO - EMEJA da SEED/MEC. Membro da Equipe de Criação, Comitê Editorial e Consultora Ad Hoc da REVEJ@ - Revista Eletrônica de EJA da UFMG. Pesquisadora cadastrada no CNPq. Representante dos Fóruns de EJA do Brasil na Comissão Nacional de Alfabetização e Educação de Jovens e Adultos - CNAEJA do MEC/SECADI. analisedasilva@ufmg.br

\section{Sobre as Editoras Convidadas}

\section{Carla Beatriz Meinerz}

Universidade Federal do Rio Grande do Sul

Doutora em Educação pela Universidade Federal do Rio Grande do Sul. Professora Adjunta no Departamento de Ensino e Currículo da Faculdade de Educação.

carlameinerz@gmail.com

\section{Dóris Maria Luzzardi Fiss}

Universidade Federal do Rio Grande do Sul

Doutora em Educação pela Universidade Federal do Rio Grande do Sul. Professora Adjunta no Departamento de Ensino e Currículo da Faculdade de Educação.

fiss.doris@gmail.com

\section{Sônia Mara Moreira Ogiba}

Universidade Federal do Rio Grande do Sul

Mestre em Educação pela Universidade Federal do Rio Grande do Sul. Professora do

Departamento de Ensino e Currículo da Faculdade de Educação. Membro da Associação

Psicanalítica de Porto Alegre (APPOA) e Instituto APPOA - Clínica, Pesquisa e Intervenção

Social. ogb@cpovo.net 


\section{DOSSIE \\ FORMAÇÃO DE PROFESSORES E PRÁTICAS CULTURAIS arquivos analíticos de políticas educativas}

Volume 21 Número 30

25 de março, 2013

ISSN 1068-2341

\section{(c)}

SORERIGHISRESERVED O Copyright e retido pelo/a o autor/a (ou primeiro co-autor) que outorga o direito da primeira publicação à revista Arquivos Analíticos de Políticas Educativas. Más informação da licença de Creative Commons encontram-se em http://creativecommons.org/licenses/by-nc-nd/2.5. Qualquer outro uso deve ser aprovado em conjunto pelo/s autor/es e por AAPE/EPAA. AAPE/EPAA é publicada por Mary Lou Fulton Institute Teachers College da Arizona State University. Os textos publicados em AAPE são indexados por CIRC (Clasificación Integrada de Revistas Científicas, Espanha) DIALNET (Espanha),Directory of Open Access Journals, Education Full Text (H.W. Wilson), EBSCO Education Research Complete, , ERIC, , QUALIS A2 (Brasil), SCImago Journal Rank; SCOPUS, SOCOLAR (China). Contribua com comentários e sugestões a http://epaa.info/wordpress/ ou para Gustavo E. Fischman fischman@asu.edu.

Curta a nossa comunidade EPAA's Facebook https://www.facebook.com/EPAAAAPE e Twitter feed@epaa_aape. 


\section{arquivos analíticos de políticas educativas conselho editorial}

Editor: Gustavo E. Fischman (Arizona State University) Editores Associados: Rosa Maria Bueno Fisher e Luis A. Gandin

(Universidade Federal do Rio Grande do Sul)

Dalila Andrade de Oliveira Universidade Federal de Minas Gerais, Brasil

Paulo Carrano Universidade Federal Fluminense, Brasil

Alicia Maria Catalano de Bonamino Pontificia Universidade Católica-Rio, Brasil

Fabiana de Amorim Marcello Universidade Luterana do Brasil, Canoas, Brasil

Alexandre Fernandez Vaz Universidade Federal de Santa Catarina, Brasil

Gaudêncio Frigotto Universidade do Estado do Rio de Janeiro, Brasil

Alfredo M Gomes Universidade Federal de Pernambuco, Brasil

Petronilha Beatriz Gonçalves e Silva Universidade Federal de São Carlos, Brasil

Nadja Herman Pontificia Universidade Católica -Rio Grande do Sul, Brasil

José Machado Pais Instituto de Ciências Sociais da Universidade de Lisboa, Portugal

Wenceslao Machado de Oliveira Jr. Universidade Estadual de Campinas, Brasil
Jefferson Mainardes Universidade Estadual de Ponta Grossa, Brasil

Luciano Mendes de Faria Filho Universidade Federal de Minas Gerais, Brasil

Lia Raquel Moreira Oliveira Universidade do Minho, Portugal

Belmira Oliveira Bueno Universidade de São Paulo, Brasil

António Teodoro Universidade Lusófona, Portugal

Pia L. Wong California State University Sacramento, U.S.A

Sandra Regina Sales Universidade Federal Rural do Rio de Janeiro, Brasil

Elba Siqueira Sá Barreto_Fundação Carlos Chagas, Brasil

Manuela Terrasêca Universidade do Porto, Portugal

Robert Verhine Universidade Federal da Bahia, Brasil

Antônio A. S. Zuin Universidade Federal de São Carlos, Brasil 


\section{education policy analysis archives editorial board}

Editor Gustavo E. Fischman (Arizona State University)

Associate Editors: David R. Garcia (Arizona State University), Stephen Lawton (Arizona State University)

Rick Mintrop, (University of California, Berkeley) Jeanne M. Powers (Arizona State University)

Jessica Allen University of Colorado, Boulder

Gary Anderson New York University

Michael W. Apple University of Wisconsin, Madison

Angela Arzubiaga Arizona State University

David C. Berliner Arizona State University

Robert Bickel Marshall University

Henry Braun Boston College

Eric Camburn University of Wisconsin, Madison

Wendy C. Chi* University of Colorado, Boulder

Casey Cobb University of Connecticut

Arnold Danzig Arizona State University

Antonia Darder University of Illinois, UrbanaChampaign

Linda Darling-Hammond Stanford University

Chad d'Entremont Strategies for Children

John Diamond Harvard University

Tara Donahue Learning Point Associates

Sherman Dorn University of South Florida

Christopher Joseph Frey Bowling Green State University

Melissa Lynn Freeman* Adams State College

Amy Garrett Dikkers University of Minnesota

Gene V Glass Arizona State University

Ronald Glass University of California, Santa Cruz

Harvey Goldstein Bristol University

Jacob P. K. Gross Indiana University

Eric M. Haas WestEd

Kimberly Joy Howard* University of Southern California

Aimee Howley Ohio University

Craig Howley Ohio University

Steve Klees University of Maryland

Jaekyung Lee SUNY Buffalo
Christopher Lubienski University of Illinois, UrbanaChampaign

Sarah Lubienski University of Illinois, UrbanaChampaign

Samuel R. Lucas University of California, Berkeley

Maria Martinez-Coslo University of Texas, Arlington

William Mathis University of Colorado, Boulder

Tristan McCowan Institute of Education, London

Heinrich Mintrop University of California, Berkeley

Michele S. Moses University of Colorado, Boulder

Julianne Moss University of Melbourne

Sharon Nichols University of Texas, San Antonio

Noga O'Connor University of Iowa

João Paraskveva University of Massachusetts, Dartmouth

Laurence Parker University of Illinois, UrbanaChampaign

Susan L. Robertson Bristol University

John Rogers University of California, Los Angeles

A. G. Rud Purdue University

Felicia C. Sanders The Pennsylvania State University Janelle Scott University of California, Berkeley

Kimberly Scott Arizona State University

Dorothy Shipps Baruch College/CUNY

Maria Teresa Tatto Michigan State University

Larisa Warhol University of Connecticut

Cally Waite Social Science Research Council

John Weathers University of Colorado, Colorado Springs

Kevin Welner University of Colorado, Boulder

Ed Wiley University of Colorado, Boulder

Terrence G. Wiley Arizona State University

John Willinsky Stanford University

Kyo Yamashiro University of California, Los Angeles

* Members of the New Scholars Board 


\section{archivos analíticos de políticas educativas consejo editorial}

Editor: Gustavo E. Fischman (Arizona State University) Editores. Asociados Alejandro Canales (UNAM) y Jesús Romero Morante (Universidad de Cantabria)

Armando Alcántara Santuario Instituto de Investigaciones sobre la Universidad y la Educación, UNAM México

Claudio Almonacid Universidad Metropolitana de Ciencias de la Educación, Chile

Pilar Arnaiz Sánchez Universidad de Murcia, España

Xavier Besalú Costa Universitat de Girona, España Jose Joaquin Brunner Universidad Diego Portales, Chile

Damián Canales Sánchez Instituto Nacional para la Evaluación de la Educación, México

María Caridad García Universidad Católica del Norte, Chile

Raimundo Cuesta Fernández IES Fray Luis de León, España

Marco Antonio Delgado Fuentes Universidad Iberoamericana, México

Inés Dussel FLACSO, Argentina

Rafael Feito Alonso Universidad Complutense de Madrid, España

Pedro Flores Crespo Universidad Iberoamericana, México

Verónica García Martínez Universidad Juárez Autónoma de Tabasco, México

Francisco F. García Pérez Universidad de Sevilla, España

Edna Luna Serrano Universidad Autónoma de Baja California, México

Alma Maldonado Departamento de Investigaciones Educativas, Centro de Investigación y de Estudios Avanzados, México

Alejandro Márquez Jiménez Instituto de Investigaciones sobre la Universidad y la Educación, UNAM México

José Felipe Martínez Fernández University of California Los Angeles, USA
Fanni Muñoz Pontificia Universidad Católica de Perú

Imanol Ordorika Instituto de Investigaciones Economicas - UNAM, México

Maria Cristina Parra Sandoval Universidad de Zulia, Venezuela

Miguel A. Pereyra Universidad de Granada, España

Monica Pini Universidad Nacional de San Martín, Argentina

Paula Razquin UNESCO, Francia

Ignacio Rivas Flores Universidad de Málaga, España

Daniel Schugurensky Universidad de Toronto-Ontario Institute of Studies in Education, Canadá

Orlando Pulido Chaves Universidad Pedagógica Nacional, Colombia

José Gregorio Rodríguez Universidad Nacional de Colombia

Miriam Rodríguez Vargas Universidad Autónoma de Tamaulipas, México

Mario Rueda Beltrán Instituto de Investigaciones sobre la Universidad y la Educación, UNAM México

José Luis San Fabián Maroto Universidad de Oviedo, España

Yengny Marisol Silva Laya Universidad Iberoamericana, México

Aida Terrón Bañuelos Universidad de Oviedo, España

Jurjo Torres Santomé Universidad de la Coruña, España

Antoni Verger Planells University of Amsterdam, Holanda

Mario Yapu Universidad Para la Investigación Estratégica, Bolivia 